\title{
Agonistic Anti-OX40 Monoclonal Antibody MEDI6469
}

National Cancer Institute

\section{Source}

National Cancer Institute. Agonistic Anti-OX40 Monoclonal Antibody MEDI6469. NCI

Thesaurus. Code C117293.

An agonistic monoclonal antibody against the co-stimulatory receptor OX40 (CD134), with potential immunostimulatory and antineoplastic activities. Upon intravenous administration, anti-OX40 monoclonal antibody MEDI6469 selectively binds to and activates OX40. OX40 activation induces proliferation of effector T-lymphocytes. In the presence of tumor-associated antigens (TAAs), this may promote an immune response against the TAA-expressing tumor cells. OX40, a cell surface glycoprotein and member of the tumor necrosis factor (TNF) receptor superfamily, is expressed on T-lymphocytes and provides a co-stimulatory signal for the proliferation and survival of activated T-cells. 